\title{
Universiteit
}

Leiden

The Netherlands

\section{Turkic and Chinese loan words in Tocharian}

Lubotsky, A.; Starostin, S.

\section{Citation}

Lubotsky, A., \& Starostin, S. (2003). Turkic and Chinese loan words in Tocharian. Retrieved from https://hdl.handle.net/1887/2692

Version: $\quad$ Not Applicable (or Unknown)

License: $\quad$ Leiden University Non-exclusive license

Downloaded from: https://hdl.handle.net/1887/2692

Note: To cite this publication please use the final published version (if applicable). 


\title{
Turkic and Chinese loan words in Tocharian
}

\author{
AleXANDER Lubotsky and SERGEI StARostin
}

\section{Turkic loan words in Tocharian ${ }^{1}$}

Fourty years ago, in 1963, Werner Winter wrote: "... it clearly becomes essential to raise the question whether non-Buddhist linguistic borrowing occurred between Turkish and Tocharian." He planned a separate treatment of the problem of loan words from Turkic in Tocharian, but this project has never been realized. Recently, the Tocharo-Turkic connections were discussed by G.J. Pinault on two occasions (1998, 2001a), but the issue of possible Tocharian borrowing from Turkic was left untouched. Some linguists even consider such borrowing as intrinsically improbable, especially in prehistoric times (cf. Adams 1999: 211: "To have given both A kom and B kaum, the borrowing would have had to have been of PTch in date. So early a date might itself rule out the Turks on geographical grounds").

In the following we would like to reopen the discussion by presenting a list of possible Tocharian loan words form Turkic. The Turkic and Altaic reconstructions below are given on the basis of the forthcoming etymological dictionary of the Altaic languages by S. Starostin and his colleagues.

1. Toch. A kom, Toch. B kaum 'sun, day'< PToch. *kaun(V)- :: Proto-Turkic *gün(él) / *guná́ (OUygh. kün 'sun, day', Turkm. gün ‘id.', etc.) < Proto-Altaic *giojńu 'dawn, daylight' (Proto-

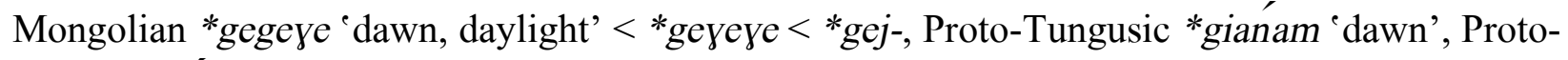
Korean *kui ' dawn', Old Japanese ke 'day').

The similarity of the Tocharian and Turkic words was noticed long ago (cf. Meillet 1914: 19: "Tel autre mot comme B kaum 'jour' rappelle le turc"). In 1941, van Windekens suggested a borrowing from Tocharian into Turkic, but Pedersen (1944: 11) argued that the direction of the borrowing must be the opposite, which was later endorsed by van Windekens (1976: 627). In his 1963 article, Winter discussed the relationship between these words. He started with the observation that "a connection between the Turkic and Tocharian words does indeed seem likely: both Old Turkish kün and Tocharian B kaum, A kom occur in combination with the equivalent of Sanskrit deva; beside Old Turkish kün we find kün tängri, beside Tocharian A kom: komñ nät, beside Tocharian B kaum: kaumñäkte. The first member of the pair refers to 'day' and 'sun', the

\footnotetext{
${ }^{1}$ We would like to express our gratitude to W. Behr, F. Kortlandt, G.-J. Pinault, and J. Wiedenhof for a number of valuable remarks on the first draft of this paper.
} 
second denotes the sun-god." Winter assumed borrowing from Tocharian into Turkic because of two considerations: (1) "The Common Turkic word for 'sun, day' (Old Turkish kün, etc.) does not seem to occur outside this subgroup of Altaic languages; in terms of Turkic morphology, the word seems unanalyzable" (1963: 239). Since the Turkic word turns out to have a good Altaic etymology, the argument naturally becomes unvalid. (2) "In B, the word for 'sun' belongs to an unproductive inflectional class." This would have been a strong counter-argument if the word was recently borrowed, but there can be no doubt that the borrowing must be dated by the ProtoTocharian period.

The whole issue depends of course on the quality of the Indo-European etymology for the Tocharian word for 'sun'. After a discussion of the previous etymological suggestions, Winter opts for the connection with Gr. $\kappa \alpha i \omega$ 'to kindle, set on fire' $<* k e h_{2} u$ - (originally proposed by Smith 1910: 10). Although this etymology seems to be generally accepted (cf. Hilmarsson 1996: 118-119, Adams 1999: 211), it is not very strong. First of all, it is a root etymology at best. There is no agreement among the scholars about the Indo-European formation which is represented in Toch. kom/kaum, and everyone devises his own morphological scenario in order to get to the attested forms. Secondly, the Greek root is isolated in Indo-European. The etymological dictionaries only mention Lith. külẽ 'ergot, smut' ('Brandpilze, Staubbrand des Getreides'), kūléti 'become blighted' ('brandig werden'), which can hardly be separated from the verb kùlti 'to thresh, thrash'. Winter's attempt to connect with Gr. koí 'morning' (Skt. śvás, Av. sūrom) has not been accep-ted by later scholarship, and probably rightly so. Thirdly, the semantic development, although feasible, is by no means evident. It seems important that the combination of the meanings 'sun' and 'day' is very unusual in the Indo-European languages, and thus is a strong indication for borrowing.

The phonetic objection raised by Adams ("In any case there is no reason *gün would have given anything but PTch **kin or **kun") is not prohibitive for borrowing, because we know very little about the Proto-Tocharian and (pre-)Proto-Turkic phonetics. There are several possible scenarios which would account for Tocharian ${ }^{*}$-au- instead of ${ }^{*}-u$-. Since PToch. ${ }^{*} u$ comes from PIE *eu, it can only occur after a palatalized consonant. It is therefore conceivable that PToch. ${ }^{*} u$ sounded as $\ddot{u}$ and was unsuitable for rendering Proto-Turkic $* u$. Alternatively, we may assume that the Turkic word for 'sun' had not yet become *gun and was still *gon- when it was borrowed with the same substitution of $o$ with au as in the word for 'dust' (see No. 3 below).

2. Toch. A àle, Toch. B alyiye* 'palm (of the hand)'< PToch. *āl'ye :: Proto-Turkic *āja 'id.' (OUygh. aja, Turkm. āja, etc.) $<* a \bar{l} l j a<$ Proto-Altaic *p ấlína (Proto-Mongolian *haliga(n), PTM *palya 'palm (of the hand)', perhaps also Proto-Korean *pār 'armful').

Pedersen (1941: 74) already warned against connecting the Tocharian word with the Indo-European family for 'elbow'. Although "it is well known that words denoting parts of the body often do not have a quite consistent meaning and tend to be transferred to other body-parts 
in the vicinity" (Hilmarsson 1986: 231-232), it remains a fact that in Indo-European languages, the word for 'elbow' is only used for the elbow-joint and for the adjacent bones, i.e. forearm (e.g. Greek and OIc.) or shoulder (Armenian). Adams (1999: 27) proposes "a semantic development from * elbow' to *'lower arm' (as in Greek for instance) $>$ *'inner surface of lower arm' > 'palm of the hand"", which may well be "within the realm of possibility", but is nevertheless highly improbable. $^{2}$

The borrowing must be fairly old, anterior to the loss of -1 - in Proto-Turkic *āja $<* \bar{a} l j a$.

3. Toch. A tor, Toch. B taur 'dust' < PToch. *taur :: Proto-Turkic *tốr 'dust' (OUygh. toz, Turkm. tōz) < Proto-Altaic *teóre 'soil, dust' (WMong. tortag 'snuff, tar', toru 'flying dust'; PTM *turV, etc.).

In 1964, van Windekens proposed to consider the Tocharian word as a loan-word from Altaic ("mongol toro"), but in his Lexique, he renounced this etymology in favor of Lane's suggestion (1938: 27) to derive the word for 'dust' from PIE * $d^{h} \mathrm{ou}(-)$ r- (thus also Adams s.v.). The problems with this derivation are obvious: the formation is unclear (the root $* d^{h}$ eur- with its two consecutive resonants has an impossible structure, so that we have to postulate an extremely rare suffix -ru- or -ri-), and the meaning of comparanda like Ru. durb 'folly' does not inspire confidence in this etymology.

Other suggestions are also semantically unsatisfactory. Winter (1982: 182) proposed to derive Toch. taur/tor from $* d^{h} \mathrm{eXwr}$ (presumably, $* d^{h} \mathrm{eh}{ }_{1} w_{0}={ }^{\prime}$ 'that which settles $=$ dust' (?), cf. Hilmarsson 1985: 43, who suggests $\left.* d^{h}(o) h_{1} w r\right)$, whereas Pinault (1994a: 375-376) favors the derivation from the PIE root *teh $2^{-}$'to thaw, dissolve', possibly with the root enlargement $-W$-, attested in Germanic (e.g. OE pāwian), i.e. *teh ${ }_{2} W-r$. Although the word for 'dust' can, theoretically speaking, be derived from either of these roots, we find nothing comparable in other Indo-European languages.

It must be stressed that the Tocharian word must have been borrowed before the Turkic change of $*^{\prime}$ to $z$.

4. Toch. B ām* 'silence', adv. 'quietly, still' :: Proto-Turkic *am- 'to be gentle, quiet' (Old Turkic amul, amil 'gentle, quiet') < Proto-Altaic *à̀mV (Proto-Mongolian *amu-, *ami- 'to rest', PTM *ām- 'to sleep').

No Indo-European etymology of Toch. B ām is known, and although the body of the word is rather short, borrowing from Turkic seems plausible.

\footnotetext{
${ }^{2}$ Adams ascribes this scenario to Hilmarsson, but it is absent from the mentioned publication. Adams further correctly dismisses other etymological suggestions as phonologically impossible (van Windekens 1976: 161 connects Lithuanian délna 'palm', OCS dlanb 'id.' and Stalmaszczyk and Witczak 1990: 39-40 connect Old Irish asil 'member'). The connection of the Tocharian word for 'palm' and Mongolian xalaqan was already considered by Róna-Tas (1974: $502=1986: 72)$, but in a very different prospective.
} 
5. Toch. A kanak, B kenek< PToch. *kenek 'cotton cloth' :: Proto-Turkic *köjye-lek, *köjnek 'shirt' (Karakh. köylek, Turkm. köjnek) < Proto-Altaic *k iun'̌́ 'thread, cloth' (Proto-Mongolian *kejey 'edge of cloth (on both sides), selvage', Proto-Korean *kính 'string, tassel', ProtoJapanese *kinú 'silk; cloth, robe').

As indicated by Pinault 2001b: 128-129, Toch. A kanak is an exact counterpart of B kenek, which does not mean 'shroud, linen cloth', as it was usually glossed, but 'cotton cloth'. In the Maitreyasamiti-Nātaka, A kanak corresponds to OUygh. böz. Pinault considers the Tocharian word to be borrowed from Iranian. Since the connection with Sogd. knc'k 'fabric', Khor. knc(y)k [kancək] 'shirt' is phonologically unsatisfactory, Pinault opts for the derivation of PToch. ${ }^{*}$ kenek (in his notation, *kœnœk) from simplified *kcœnœk < *käcœnœk and connects Khor. kcynyk 'silk cloth' with reference to Zieme 1995: 493. Although possible, the loss of -c- in this constellation in both Tocharian languages is unparalleled (especially Toch. A preserves the initial clusters rather faithfully), whereas the connection with the Turkic word, proposed here, involves no phonological or semantic difficulties (cf. for the meaning Sogd. knc'k 'fabric', Khor. $k n c(y) k$ 'shirt'). We may add that the Turkic word has also been borrowed into Mongolian (WMong. küjileg, Kalm. kīləg, MMong. kọ̈lek).

6. Toch. B olya 'more' :: Proto-Turkic *ulug 'big, great' (OUygh. uluy, Turkm. ulu etc.) < ProtoAltaic *ulu/o (Proto-Mongolian *olon 'many', PTM *ule- 'good', Proto-Korean *ōr 'completely, wholly').

The Tocharian word (also found in a compound olyapo 'more; rather (than)') has no Indo-European etymology, and borrowing is conceivable, although the source of palatalized ly is so far unclear.

7. Toch. A tmām, Toch. B t( $\left.{ }_{u}\right)$ māne 'ten thousand, a myriad' < PToch. *t(ə)māne :: Proto-Turkic *Tümen ‘ten thousand; very many' (OUygh. tümen, Turkm. tümen) < Proto-Altaic *čiumi ‘a large number' (e.g. Proto-Korean *čimín 'thousand').

Tocharian may have borrowed this Turkic word through a Middle Iranian intermediary (cf. Modern Persian tumān 'ten thousand'), which would better account for the vocalism.

8. Toch. B pärseri* '(head-)louse’: Proto-Turkic *bürče 'flea' (Tat. börčc, Kum. bürče, Chuv. pъ$^{{ }^{W}}$ rźa, etc.) < Proto-Altaic *biure (WMong. bürge, büürge 'louse', Proto-Korean *pjə’rók 'flea').

No Indo-European etymology of Toch. B pärśeri* (also appearing in the mss. as pärșere*) is known. The meaning of the Tocharian word is somewhat uncertain, but it is suggested by the following context: ấsne yamașälle pärṣerem nakṣäm 'it [is] to be put on the head; it destroys lice' (W-3a4), cf. Adams s.v. The variation pärșere* : pärśseri* may indicate that this is a loan word. The Tocharian vocalism points to a recent date of borrowing, but the suffix -re-/-ri- remains unaccounted for. 
9. Toch. B yase* 'shame': Proto-Turkic *jās 'loss, damage, shame' (OUygh. jas 'loss, damage', Yak. sāt 'shame' etc.) < Proto-Altaic *ziāsu 'loss, damage'.

The Tocharian word is only attested in a compound yase-kwipe 'shame and modesty (vel sim.)', which makes it difficult to assess the original quality of the -a-. Adams s.v. writes: "The consistent marking of stress on the first vowel of kwipe suggests it is not a full compound", i.e. that both members have retained their accent. In that case, yase must go back to *yäse. If, however, we assume that the form of the simplex (kwipe) was introduced into the compound and that the compound was accented on the second syllable as expected, yase ro reflects earlier *yāsé.

The etymology, accepted in van Windekens 1976: 586 and Adams s.v., viz. that yase is a derivative of the root yäs-/yās- 'to excite sexually', is semantically unsatisfactory.

10. Toch. AB kärk- 'rob, steal': Proto-Turkic *Kar-ak 'bandit' (OUygh. qaraq-čí, Turkm. Garak etc.) < Proto-Altaic *kara 'opposite; enemy'.

Since the Tocharian verb has no reliable Indo-European etymology, borrowing can be considered. Although verbs are not easily borrowed, we may assume that Toch. kärk- is an original denominative. The verbal paradigm of kärk- (in B: pres. VI kärknamane, also reflected in a verbal adjective kärkänamo 'robber', Subj. V inf. kärkatsi, Pret. Ia kärkāte; in A only inf. kärnātsi) is likely to have been taken over from the rhyming tärk- (especially, since the Toch. B compound cowai tärk- also means 'to rob') and cannot thus be used as an argument against borrowing.

The presented etymologies seem to indicate an early date of borrowing. Some of the loan words must already have been borrowed during the Common Tocharian period, and some represent the stage anterior to the Proto-Turkic sound changes ${ }^{*} l j>j$ and ${ }^{*} r>z$. The latter would date the Turco-Tocharian contacts by a period prior to the separation of the Bulgar (Chuvash) branch, most probably around the beginning of our era. The geographical location of Turks at that time is not clear enough, but we may suppose an area somewhere in the vicinity of Turfan, where the oldest Uyghur texts are found.

\section{Chinese loan words}

Whereas Tocharian borrowing from Turkic has not yet been accepted in Tocharology, Tocharian loan words from Chinese are well-known ${ }^{3}$. Adams in his dictionary ${ }^{4}$ mentions the following words as having been borrowed from Chinese ${ }^{5}$ :

\footnotetext{
${ }^{3}$ For a recent discussion of the Chinese words for various measures borrowed in Tocharian, cf. Pinault 1994b: 93.

${ }^{4}$ This collection is based on a search in the Tocharian database on the site of the "Indo-European Etymological Dictionary" project (URL-address: www.ieed.nl). The Chinese reconstructions are taken from S. Starostin's database of Chinese characters on the site of the "Tower of Babel" project (URL-address: starling.rinet.ru). The minor differences among the current reconstructions of Baxter and Starostin are irrelevant for our purpose.

${ }^{5}$ The etymology of two words is uncertain. (1) Toch. A nkinc, Toch. B ñkante* 'silver' are usually taken to be loan words from Chinese 銀 yín 'silver' (< MC gin, OC *grən), provided with Tocharian suffixes, but Witczak (1990)
} 
1. Toch. AB klu 'rice' :: Chin. 稻 dào 'rice plant' $<$ MC dấw $<$ OC *Łhü? (cf. also Blažek 1999: 81f);

2. Toch. B rapaññe (adj.) 'of the last month of the year' :: Chin. 臘 là 'winter sacrifice' $<$ MC lâp $<$ OC *rāp;

3. Toch. B cāk 'hundred quarts [dry measure]' :: Chin. 石 shí 'stone, measure of weight, measure of capacity (= $10 \mathrm{doru})^{\prime}<\mathrm{MC}$ źek $<$ OC diak;

4. Toch. B cāne* a unit of money :: Chin. 錢 qián 'money' < MC zjen $<$ OC źan;

5. Toch. B tau 'ten quarts (dry measure)' :: Chin. 斗 dǒu 'ladle, dipper, measure of dry goods' < $\mathrm{MC} t_{\Lambda}^{\prime} W<\mathrm{OC}$ tō?

6. Toch. B '́ak(u)se* 'brandy' :: Chin. 粟 sù 'grain (rice or millet) in husk' $<$ MC sjöuk $<$ OC sok + Chin. 酒 jiŭ 'wine' < MC cjów $<$ OC cu?;

7. Toch. B șank, a wet or dry measure of volume (1.1-1.2 liters or 1.2-1.3 quarts) :: Chin. 升 shēng 'a measure of weight (one tenth of a dóu)' $<$ MC śin $<$ OC təy;

8. Toch. A yāmutsi, Toch. B yāmuttsi a kind of waterfowl [= BHS hamsa-] :: Chin. yīng-wǔ-(zi) 胺鳥武鳥 (子) < MC Pạin-mü-cjí < OC *Prēy-ma?- 'parrot', cf. also Sogdian 'ym’wtsy /ēmūtsi/ 'parrot' from the same source. Adams s.v. doubts this etymology ("Against this derivation are difficulties both phonological (the first syllable of the Tocharian forms certainly does not match either the Chinese or the Sogdian) and semantic (both the Chinese and the Sogdian mean 'parrot')"), but both considerations do not seem serious enough to preclude borrowing from Chinese (possibly, through Iranian mediation).

Grenet and Pinault (1997: 1016-1022) added two more clear Chinese loan words:

9. Toch. B șitsok 'millet-alcohol' :: Chin. 乘 shǔ 'glutinous millet (Panicum miliaceum)' $<\mathrm{MC}$ sö < OC sla? $(\sim \chi-)+$ 酒 jiǔ 'wine' < MC cjów < OC cu? (Grenet - Pinault 1997: 1016-1018).

It is peculiar that the Chinese word for 'wine, alcohol' is reflected in two different shapes in Tocharian, viz. as -tsok here and as -se in $\operatorname{sak}(u){ }^{2} e^{*}$ 'brandy' (cf. number 6 above). It is conceivable that -tsok is influenced in its form by the verb tsuk- 'to drink'. The correlation of MC $s^{\prime} \ddot{o}=$ Tokh. și-in a disyllabic word is strengthened by the next case.

suggested that this word may reflect PIE * $h_{2}$ regnóntom (cf. Sanskrit rajatám 'silver') with assimilation to * $h_{2}$ negñtom $>\tilde{n}$ kante. (2) Toch. B kapci 'thumbprint (?), authentication' is "certainly a borrowing from the Chinese, but the details are obscure" (Adams s.v. with a reference to the article by Kumamoto in Emmerick and Skjærvø 1987:151154). Jeroen Wiedenhof (p.c.) suggests that the Tocharian word may represent Chin. 押字 yā-zi to authenticate with a signature' ('signature, mark, pledge' + 'written character'), MC Pạp-3jì with Chinese glottal closure being rendered as initial $k$ - in Tocharian. This seems to be a distinct possibility, but since the precise meaning of Toch. B kapci is unknown, we cannot be sure. 
10. Toch. B șipānkiñn 'abacus’. The first part clearly resembles Chin. 數盤 shǔ-pán, MC șü-bân (OC *sro?-bān) 'counting board, tally, abacus', but the second part is so far less clear. Grenet and Pinault (1997: 1020-1022) suggest that it may represent Chin. 工具 gōngju 'instrument', MC kuy-gü (OC kōy-gos).

This list of Chinese loan words in Tocharian can further be expanded. ${ }^{6}$

11. Toch. AB cok 'lamp' :: Chin. 燭 zhú ' torch, candle; shine' $<$ MC cöuk $<$ OC tok. ${ }^{7}$

Traditionally, Toch. AB cok was etymologized as PIE $* d^{h} \bar{e} g^{w h} u-$, a derivative of the root tsäk- $<* d^{h} \mathrm{eg}^{\text {wh }}$ - 'to burn', but this etymology is phonologically difficult, because palatalized $t s$ appears in Tocharian as Ś, and not c. Therefore, Winter (1962: 18) wrote: "Das Beispiel cok bleibt unsicher -- er gehört in B zu einer Deklinationsklasse, die besonders bei Lehnwörtern productiv geworden ist ..., und ist daher möglicherweise fremder Herkunft". Other etymological explanations from Indo-European are also improbable (see Adams 1999: 256 for an overview).

12. Toch. A trunk, B tronk* 'hollow, cave’, B tronktse (adj.) ‘hollow’ < PToch. * tronk :: Chin. 盅 chōng, chǒng 'empty, hollow' < MC thün < OC *thruy, ${ }^{8}$ with further Sino-Tibetan connections, cf. Tibetan doy 'a deep hole, pit, ditch', stoy 'empty, clear, hollow', stoys 'to make empty', Burmese twayh 'hole in the ground, pit', thwayh 'to make a hole'.

Extra-Tocharian connections within Indo-European are unclear (for a review of the previous suggestions see Adams 1999: 321-322).

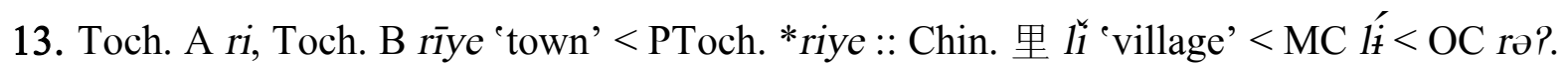

In 1998, Lubotsky (p. 368) proposed to consider borrowing in the opposite direction (from Tocharian into Chinese). The problem is, however, that the only sure extra-Tocharian relative is the Thracian $\beta$ pí $\alpha$, presumably /uria/, mentioned by Strabo as a Thracian word for $\pi$ ó $\lambda \imath \varsigma, \tau \varepsilon \tilde{i} \chi 0 \varsigma$ and glossed by Hesych as $\kappa \omega ́ \mu \eta$. The Indo-European etymology of Toch. A ri, Toch. B riye is thus rather questionable. On the other hand, Peiros and Starostin (1996,2: 77) reconstruct Sino-Tibetan *riəH, adducing Jingpo more ${ }^{1}$ 'town'. If this Sino-Tibetan reconstruction is correct, the Tocharian word is likely to be borrowed from Chinese.

14. Toch. A lyäk, Toch. B lyak 'thief' < PToch. *lyäk :: Chin. 掠 lüe 'to plunder, rob; be rapacious' < Late MC liak < MC lak < OC rhak. Peiros and Starostin (1996, 2: 96) reconstruct SinoTibetan *rǒk (Tibetan ãphrog 'to rob, take away, to deprive of', Lushan rok 'to plunder, loot, spoil').

\footnotetext{
${ }^{6}$ In a recent article, K.T. Schmidt mentioned two more possible Tocharian (B) borrowings from Chinese: "Die neuentdeckten Bezeichnungen für Längenmaße, tsum 'Zoll' und cak 'Fuß', sind dem Chinesischen entlehnt" (1999: 19). Unfortunately, Schmidt does not give any references as to where and in which context these words are found. He presumably assumes that they have been borrowed from Chin. 寸 cun 'inch' $<$ MC chòn $<$ OC shün-s and Chin. 尺 chí 'one foot $(=22.5 \mathrm{~cm})^{\prime}<\mathrm{MC}$ ć $\mathrm{e} k<\mathrm{OC}$ thiak, respectively.

7 An archaic Vietnamese loan from the same source is duôc 'torch'.

${ }^{8}$ Also read *dhruy, MC ḍ̈y 'id.'. Mod. reading zhōng is secondary, on analogy with 中 *truy, 'middle'.
} 
No less than three Indo-European etymologies have been proposed for this Tocharian word: a root noun derived (1) from PIE * $l \mathrm{eg}^{h}$ - 'lie (down)', thus 'one who lies (in wait)', (2) from PIE *lek- 'fly' seen in Lithuanian lekkiu 'fly, run' (*'cause to fly' > *'fly off with' > 'steal', cf. French voler), and (3) from PIE *leg- (Gr. $\lambda \dot{\varepsilon} \gamma \omega)$ 'to collect'. The first two etymologies are discussed by Adams (1999: 565), the third is by Pinault (apud Hilmarsson 1996: 87). All of them are phonologically impeccable, but not very probable on the semantic side.

15. Toch. AB tsem ‘blue' :: Chin. 青 qīng ‘be blue, green’ < MC chiey < OC chēy.

Tocharian A e and B e do not correspond etymologically, so that Toch. A has probably borrowed this word from B. ${ }^{9}$ The proposed Indo-European etymologies are improbable (PIE $* d^{h}$ us-on- to Old English dosen 'dark brown', Latin furvus 'dark, black', etc.), and in view of the almost perfect correspondence with the Middle Chinese form, borrowing can hardly be doubted.

We can distinguish two groups of Chinese loan words in Tocharian:

1) Early loans (words for 'rice', 'winter sacrifice', 'cave', 'town'), showing pre-Han or Early Han phonetic peculiarities (Toch. $k l-=$ OC $E$ - (l-) vs. MC d-, Toch. $r-=$ OC $r$ - vs. MC 1 -, Toch. tr- $=$ OC tr-vs. MC $t$-). They must have entered Tocharian not later than the 2nd century B.C.

2) Middle Chinese loan words (measures, alcoholic drinks, 'money', 'waterfowl', 'torch', 'thief', 'abacus', perhaps also 'silver' and 'authentication'). These words exhibit typical Middle Chinese phonetic features (affricates instead of dentals before original fronted $(<*$ short) vowels, MC 1 instead of OC ${ }^{*} r$-, loss of medial $-r$-, usually typical MC vocalism). Note, however, back -a- in $c \bar{a} k=\mathrm{MC}$ źek $(\mathrm{OC} *$ diak$)$ and cāne = MC zjen (OC *'zan), which may indicate that those words were borrowed somewhat earlier than Middle Chinese (7th century A.D.), possibly in the 3rd or 4th century A.D.

Available evidence, therefore, allows to conclude that Tocharo-Turkic contacts should be dated by a rather early period (possibly synchronic with the earliest Tocharo-Chinese contacts), but the Chinese influence was more lasting and continued from the 3rd or 2 nd centuries B.C. until the Middle Chinese period (around 7th century A.D.).

\section{References}

Adams, Douglas Q.

1999 A dictionary of Tocharian B. Amsterdam - Atlanta: Rodopi.

Blažek, Vaclav

1999 Alimenta Tocharica. Tocharian and Indo-European Studies 8: 79-84.

Emmerick, Ronald E. and Prods Oktor Skjærvø

1987 Studies in the vocabulary of Khotanese II. Wien: Österreichische Akademie der Wissenschaften.

\footnotetext{
${ }^{9}$ The Proto-Tocharian reconstruction given by Adams (s.v.) is fictitious.
} 
Grenet, Franz and Georges-Jean Pinault

1997 Contacts des traditions astrologiques de l'Inde et de l'Iran d'apres une peinture des collections de Turfan. Comptes rendus de l'Académie des Inscriptions \& Belles-Lettres 1997: 1003-1061.

Hilmarsson, Jörundur

1985 Tocharian B kroriyai (obl.sg.), A kror 'crescent, horn of the moon'. Die Sprache 31: 4047.

1986 Studies in Tocharian phonology, morphology, and etymology with special emphasis on the o-vocalism. Reykjavik: Málvísindastofnun Háskóla Íslands.

1996 Materials for a Tocharian historical and etymological dictionary. Reykjavík: Málvísindastofnun Háskóla Íslands.

Lane, George Sherman

1938 Problems of Tocharian phonology. Language 14: 20-38.

Lubotsky, Alexander

1998 Tocharian loan words in Old Chinese: chariots, chariot gear, and town building. In: Victor A. Mair (ed.), The Bronze Age and Early Iron Age peoples of Central Asia, 379390, Washington D.C.: Institute for the Study of Man.

Meillet, Antoine

1914 Le Tokharien. Indogermanisches Jahrbuch 1: 1-19.

Pedersen, Holger

1941 Tocharisch vom Gesichtspunkt der indoeuropäischen Sprachvergleichung (Det Kgl. Danske Videnskabernes Selskab. Historisk-filologiske Meddelelser XXVIII,1). København: I kommission hos Ejnar Munksgaard.

1944 Zur tocharischen Sprachgeschichte. København.

Peiros, Ilia and Sergej Starostin

1996 A comparative vocabulary of five Sino-Tibetan languages. 6 vols. Melbourne: The University of Melbourne, Department of Linguistics and Applied Linguistics.

Pinault, Georges-Jean

1994a Lumières tokhariennes sur l'indo-européen. In: Jens E. Rasmussen (ed.), In honorem Holger Pedersen. Kolloquium der Indogermanischen Gesellschaft vom 26. bis 28. März 1993 in Kopenhagen, 365-396, Wiesbaden: Reichert.

1994b Aspects du bouddhisme pratiqué au nord du désert du Taklamakan, d'aprés les documents tokhariens. Bouddhisme et cultures locales. Quelques cas de réciproques adaptations. (Actes du colloque franco-japonais de septembre 1991). Paris: EFEO.

1998 Tocharian languages and pre-Buddhist culture. In: Victor A. Mair (ed.), The Bronze Age and Early Iron Age peoples of Central Asia, 358-371, Washington D.C.: Institute for the Study of Man.

2001a Tocharo-Turcica. In: L. Bazin, P. Zieme (eds.), De Dunhuang à Istanbul. Hommage à James Russel Hamilton, (Silk Road Studies V), 245-265, Turnhout: Brepols.

$2001 \mathrm{~b}$ Nouveautes lexicales et morphologiques dans le manuscrit de Yanqi du MaitreyasamitiNātaka en tokharien A. In: Stefan Wild and Hartmut Schild (eds.). Akten des 27. 
Deutschen Orientalistentages (Bonn - 28. September bis 2. Oktober 1998). Norm und Abweichung,121-136. Würzburg: Ergon.

Róna-Tas, Andras

1974 Tocharische Elemente in den altaischen Sprachen? Sprache, Geschichte und Kultur der altaischen Völker. Protokollband der XII. Tagung der Permanent International Altaistic Conference 1961 in Berlin, 499-504, Berlin: Akademie-Verlag.

1986 Language and history. Contributions to comparative Altaistics. Szeged.

Schmidt, Klaus T.

1999 Beobachtungen zur tocharischen Landwirtschaftsterminologie. Sprache 41: 1-23.

Smith E.

1910 "Tocharisch". Die neuentdeckte indogermanische Sprache Mittelasiens. Vid. Selsk. Skriften, II. Hist-fil. K1. 1910, Nr. 2. Christiania.

Stalmaszczyk, Piotr and Krzysztof T. Witczak

1990 Celto-Tocharica I. Three Celtic-Tocharian terms for certain parts of the body. Tocharian and Indo-European Studies 4: 35-44.

Starostin, Sergej A. - Anna V. Dybo - Oleg A. Mudrak

forthcoming: An etymological dictionary of Altaic languages. Leiden: Brill. [The Altaic database can also be consulted on the site of the "Tower of Babel" project (the URL-address of the site is starling.rinet.ru).]

Van Windekens, Albert Joris

1941 Lexique étymologique des dialectes tokhariens. Louvain: Muséon.

1964 Sur quelques mots tokhariens provenants de langues asiatiques indo-européennes et nonindo-européennes. Orbis 13: 589-597.

1976 Le tokharien confronté avec les autres langues indo-européennes, Vol. I. La phonétique et le vocabulaire. Louvain: Centre International de Dialectologie Générale.

1977 Recherches complémentaires sur le vocabulaire tokharien I. Orbis 26: 141-148.

Winter, Werner

1962 Die Vertretung indogermanischer Dentale im Tocharischen. Indogermanische Forschungen 67: 16-35.

1963 Tocharians and Turks. Uralic and Altaic Studies 23: 239-251.

1982 Indo-European words for "tongue" and "fish": A reappraisal. The Journal of IndoEuropean Studies 10: 167-186.

Witczak, Krzysztof T.

1990 Tocharian A nkiñc, B ñkante 'silver'. Tocharian and Indo-European Studies 4: 47-48.

Zieme, Peter

1995 Philologische Bemerkungen zu einigen alttürkischen Stoffnamen. Acta Orientalia Academiae Scientiarum Hung. 48: 487-94. 


\section{Abbreviations}

Chin. (Modern) Chinese

Chuv. Chuvash

Kalm. Kalmuck

Karakh. Karakhanide Turkic

Khor. Khorasmian

Kum. Kumyk

MC Middle Chinese

MMong. Modern Mongolian

OC Old Chinese

OUygh. Old Uyghur

PIE Proto-Indo-European

PToch. Proto-Tocharian

Ru. Russian

Sogd. Sogdian

Tat. Tatar

Toch. Tocharian

PTM Proto-Tungus-Manchu

Turkm. Turkmenian

WMong. Written Mongolian

Yak. Yakut 